\title{
PENGARUH PEMANFAATAN BONGGOL PISANG SEPATU (Musa paradisiaca L) DALAM RANSUM TERHADAP PERSENTASE KARKAS DAN LEMAK ABDOMINAL AYAM BROILER
}

\author{
Sulastri G. Pontoh, J. Mandey*, F. R. Wolayan, Y. Kowel \\ Fakultas Peternakan Universitas Sam Ratulangi Manado
}

\begin{abstract}
ABSTRAK
Penelitian ini dilaksanakan untuk mengetahui pengaruh pemberian bonggol pisang sepatu dalam ransum terhadap presentase karkas dan lemak abdominal ayam broiler. Lama penelitian selama 5 minggu menggunakan 100 ekor ayam broiler unsexed strain Cobb (PT. Charoen Pokhpand) umur 1 hari. Metode penelitian adalah Rancangan Acak Lengkap dengan 4 perlakuan 5 ulangan dengan tingkat pemberian bonggol pisang sepatu dalam ransum yaitu R0: 0\%, R1: 5\%, R2: 10\%, R3: $15 \%$. Variabel penelitian adalah presentase karkas dan lemak abdominal ayam broiler. Hasil penelitian menunjukkan bahwa rataan presentase karkas: 63,44 - 66,32\% dan rataan lemak abdominal: 1,8 -2,33\%. Berdasarkan hasil analisis pemberian bonggol pisang dalam ransum memberikan pengaruh yang tidak berbeda nyata $(\mathrm{P}>0.05)$. Kesimpulan dari penelitian ini adalah bahwa pemberian bonggol pisang sepatu (Musa paradisiaca L.) sebagai pengganti jagung sampai dengan $15 \%$ menghasilkan presentase karkas dan lemak abdominal yang baik
\end{abstract}

Kata kunci: Ayam broiler, bonggol pisang, presentase karkas dan lemak abdominal.

\footnotetext{
*Korespondensi (Correponding author) Email: jetsm_fapet@yahoo.co.id
}

\begin{abstract}
THE INFLUENCE OF THE USE OF BANANA HUMP SHOES (Musa paradisiaca L) IN RATION ON THE PERCENTAGE OF CARCASS AND ABDOMINAL FAT IN BROILER CHICKEN. This study aims to determine the extent of the effect of using banana hump shoes (Musa Paradisiaca) in rations on carcass and abdominal fat in broiler chickens. This study was conducted using 100 unsexed Cobb broiler chickens (PT. Charoen Pokhpand), with an average body weight of 837 grams. The design used was a Completely Randomized Design (CRD) consisting of 4 treatments and 5 replications. Arrangement of the experimental treatment as follows: $\mathrm{R}_{0}=$ $55 \%$ corn $+0 \%$ banana hump shoes, $\mathrm{R}_{1}=$ $50 \%$ corn $+5 \%$ banana hump shoes, $\mathrm{R}_{2}=$ $45 \%$ corn $+10 \%$ banana hump shoes, $\mathrm{R}_{3}=$ $40 \%$ corn $+15 \%$ banana hump shoes. The results showed that there was no significant difference $(\mathrm{P}>0,05)$ on the percentage of carcass and abdominal fat in broiler chickens. Based on the results of this study it can be concluded that the use of banana shoe hump in rations up to $15 \%$ produces a good percentage of carcass and abdominal fat.
\end{abstract}

Keywords: broiler chicken, banana hump shoes, percentage of carcass and abdominal fat. 


\section{PENDAHULUAN}

Peningkatan jumlah penduduk Indonesia dari tahun ke tahun berdampak pada peningkatan konsumsi produk peternakan (daging) yang secara tidak langsung memberikan peluang usaha dalam memajukan industri peternakan di Indonesia. Ternak unggas memberikan kontribusi yang besar terhadap pemenuhan gizi khususnya protein hewani. Ayam broiler adalah ternak unggas yang dapat menghasilkan daging dalam waktu yang relatif singkat, karena memiliki kemampuan genetik untuk bertumbuh dengan cepat, yaitu 5-6 minggu dengan bobot badan sekitar 1,3-1,6 kg (Koni, 2013). Ayam broiler adalah ayam yang diciptakan dari perkawinan silang, seleksi, dan rekayasa genetic (Tamalludin, 2012). Data Dirjen Peternakan dan Kesehatan Hewan 2014 ternak unggas memberi sumbangan daging untuk kebutuhan nasional sebesar $66,27 \%$ dan dari jumlah tersebut ayam ras pedaging menyumbang $77,17 \%$.

Ayam broiler merupakan salah satu produk dari sub sektor peternakan yang memerlukan pakan dalam jumlah yang tinggi karena pertumbuhannya sangat tergantung pada pemberian ransum (Achmad dan Amir, 2006). Penyediaan bahan baku pakan hingga kini belum tertanggulangi dengan baik, dalam arti kompetisi pangan dan pakan masih terus berlanjut, sehingga menimbulkan dilema bagi nutrisionis dan konsumen. Di samping itu, penyediaan bahan pakan sering mengalami kendala yaitu mahalnya harga pakan akibat sebagian bahan pakan tersebut seperti tepung ikan, jagung dan kedele masih didatangkan dari luar daerah, bahkan dari luar negeri, sehingga pada akhirnya akan meningkatkan biaya produksi.

Usaha untuk mengatasi ketersediaan jagung yang semakin terbatas yaitu dengan mencari bahan pakan alternatif yang kualitasnya hampir sama dengan jagung. Salah satu bahan pakan yang tersedia dan belum sepenuhnya digunakan dalam ransum, khususnya ransum unggas, yaitu bonggol pisang sepatu (Musa paradisiaca L.) yang dapat dijadikan suatu pilihan untuk penyediaan pakan sumber energi.

Keunggulan dari bonggol pisang sepatu (Musa paradisiaca L.) sebagai bahan pakan adalah kandungan patinya yang tinggi. Kandungan bonggol pisang yaitu sebagai berikut: protein $2,38 \%$, serat kasar 4,47\%, lemak 0,87\%, kalsium 0,06\%, fosfor $0,15 \%$, dan energi bruto $3202 \mathrm{kkal}$ (Analisis Laboratorium Ilmu Makanan Ternak Fakultas Peternakan UGM, Yogyakarta, 2017).

Berdasarkan latar belakang pemikiran di atas, maka telah dilakukan penelitian mengenai pengaruh pemanfaatan 
bonggol pisang sepatu (Musa paradisiaca L.) dalam ransum dengan tujuan untuk melihat sejauh mana pengaruhnya terhadap presentase karkas dan lemak abdominal ayam broiler.

\section{MATERI DAN METODE PENELITIAN}

Penelitian ini telah dilaksanakan di kandang percobaan unggas Jurusan Nutrisi dan Makanan Ternak, Fakultas Peternakan Univeristas Sam Ratulangi Manado, selama 5 minggu (dari tanggal 7 Desember sampai 2017 sampai dengan 15 Januari 2018). Kandang yang digunakan adalah jenis kandang battery berukuran $20 \times 30 \times 30 \mathrm{~cm}$ terdiri dari 20 unit kandang, dimana setiap unit ditempati 5 ekor ayam. Setiap kandang dilengkapi tempat makan dan minum. Perlengkapan lain yang digunakan yaitu lampu pijar 60 watt, timbangan digital ohaus, wadah untuk mencampur ransum perlakuan, koran bekas, ember, kuas dan sendok untuk mengambil ransum sisa, sapu lantai, dan alat tulis menulis.

Penelitian ini menggunakan metode eksperimen dengan Rancangan Acak Lengkap (RAL) Steel and Torrie (1991), yang terdiri dari 4 perlakuan dan 5 ulangan. Setiap ulangan terdiri dari 5 ekor ayam pedaging, sehingga jumlah keseluruhan ayam pedaging yang digunakan dalam penelitian ini adalah 100 ekor.

Susunan ransum perlakuan sebagai berikut :

$\mathrm{R} 0=55 \%$ jagung $+0 \%$ tepung bonggol pisang sepatu

$\mathrm{R} 1=50 \%$ jagung $+5 \%$ tepung bonggol pisang sepatu

$\mathrm{R} 2=45 \%$ jagung $+10 \%$ tepung bonggol pisang sepatu

$\mathrm{R} 3=40 \%$ jagung $+15 \%$ tepung bonggol pisang sepatu

Ternak percobaan diletakan atau ditempatkan secara acak ke dalam 20 unit kandang, dengan tiap unit ditempatkan 5 ekor ayam broiler umur 1 hari dan juga penempatan perlakuan secara acak. Pemberian ransum percobaan sudah dilakukan pada ayam broiler umur 1 hari dan diberikan secara adlibitum, begitu pula dengan pemberian air minum. Ayam dipotong pada akhir minggu ke 5 setelah ditimbang berat badan akhir. Karkas dihitung dari berat bagian tubuh ayam tanpa bulu, kepala, kaki, seluruh isi rongga perut kecuali hati, rempela, dan jantung. Lemak abdomen dipisahkan kemudian ditimbang selanjutnya data ditabulasi dan dianalisis. Berikut ini proses pembuatan tepung bonggol pisang sepatu: Bonggol pisang sepatu segar, dipotong - potong kecil (sekitar 1-3 cm), dijemur, 
Tabel 1. Komposisi Zat-Zat Makanan dan Energi Metabolis Bahan Pakan Penyusun Ransum

\begin{tabular}{lllllll}
\hline Bahan Makanan & Protein & $\begin{array}{l}\text { Serat } \\
\text { Kasar }\end{array}$ & Lemak & Ca & P & $\begin{array}{l}\text { Energi } \\
\text { Metabolis }\end{array}$ \\
\hline Bonggol Pisang** & 2,38 & 4,47 & 0,87 & 0,06 & 0,15 & 3203 \\
Jagung* & 8,01 & 3,45 & 7,71 & 0,17 & 0,70 & 2865,75 \\
Tepung Kedelai * & 42,02 & 6,40 & 13,22 & 0,21 & 0,65 & 3603 \\
Bungkil Kelapa* & 20,55 & 15,88 & 15,07 & 0,21 & 0,49 & 3724,5 \\
Dedak* & 8,36 & 16,53 & 6,58 & 0,18 & 0,84 & 2564,25 \\
Tepung Ikan* & 63,6 & 0,5 & 9,3 & 5,81 & 3,23 & 2830 \\
Top Mix* & - & - & - & 5,38 & 1,44 & - \\
\hline
\end{tabular}

Keterangan: * Hasil Analisis Laboratorium Ruminansia \& Kimia Makanan Fakultas Peternakan Unpad, Bandung, (2017)

** Hasil Analisis Laboratorium Ilmu Makanan Ternak Fakultas Peternakan UGM, Yogyakarta (2017)

Tabel 2. Susunan Ransum Perlakuan Serta Komposisi Zat-zat Makanan dan Energi Metabolis

\begin{tabular}{llccc}
\hline Bahan Ransum & $\mathrm{R}_{0}$ & $\mathrm{R}_{1}$ & $\mathrm{R}_{2}$ & $\mathrm{R}_{3}$ \\
\hline Bonggol Pisang (\%) & 0 & 5 & 10 & 15 \\
Jagung (\%) & 55 & 50 & 45 & 40 \\
Tepung Kedelai (\%) & 10 & 10 & 10 & 10 \\
Bungkil Kelapa (\%) & 10 & 10 & 10 & 10 \\
Dedak (\%) & 9,5 & 9,5 & 9,5 & 9,5 \\
Tepung Ikan (\%) & 15 & 15 & 15 & 15 \\
Top Mix (\%) & 0,5 & 0,5 & 0,5 & 0,5 \\
\hline Total & 100 & 100 & 100 & 100 \\
\hline Zat-Zat Makanan* & & & & \\
\hline Protein (\%) & 20,88 & 20,59 & 20,31 & 20,03 \\
Serat Kasar (\%) & 5,69 & 4,16 & 5,79 & 5,84 \\
Lemak (\%) & 10,19 & 9,85 & 9,51 & 9,17 \\
Ca (\%) & 0,33 & 0,29 & 0,29 & 0,28 \\
P (\%) & 0,68 & 0,65 & 0,63 & 0,60 \\
Energi Metabolis (Kkal/kg) & 2977,01 & 2993,87 & 2977 & 3027,6 \\
\hline Keterangan:Dihitung berdasark Tabel & & &
\end{tabular}

Keterangan:*Dihitung berdasarkan Tabel 1. 
digiling/dihaluskan, tepung bonggol pisang.

\section{HASIL DAN PEMBAHASAN}

\section{Pengaruh Perlakuan Terhadap Persentase Karkas}

Data hasil perhitungan rataan persentase karkas dari masing-masing perlakuan yang diberikan selama penelitian dapat dilihat pada Tabel 3.

Rata-rata persentase karkas ayam broiler umur 5 minggu dengan level pemberian bonggol pisang sepatu yang berbeda berkisar antara 63,04-66,32\% dengan rataan tertinggi pada perlakuan R0 (tanpa bonggol pisang sepatu) dan terendah pada perlakuan R3 (penggantian 15\% bonggol pisang sepatu). Hal tersebut sesuai dengan penelitian Pesti dan Bakali (1997) yang memperoleh karkas ayam broiler berkisar antara 60,52\%-69,91\% dari bobot hidup dan penelitian Dewi (2007) yang memberikan ransum komersil memperoleh 63,79\%-67,78\% dari bobot hidup. Menurut Suprayitno dan Indraji (2007) rataan persentase berat karkas ayam broiler umur 5 minggu adalah 59-63\% dari berat hidup. Sedangkan Sumarni (2015), menyatakan bahwa rataan persentase bobot karkas 69,76-73,39\% dimana persentasenya lebih tinggi dari penelitian ini.
Hasil analisis ragam menunjukan bahwa pemberian level bonggol pisang sepatu dengan level berbeda memberikan pengaruh tidak berbeda nyata $(\mathrm{P}<0,05)$ pada persentase karkas ayam broiler umur 5 minggu. Hal ini mengindikasikan bahwa penggunaan bonggol pisang sepatu hingga $15 \%$ dalam ransum tidak memberikan pengaruh yang nyata terhadap presentase karkas ayam broiler. Tidak adanya pengaruh perlakuan terhadap presentase karkas disebabkan oleh kandungan nutrisi dalam ransum yang relatif sama, khususnya protein yang berfungsi sebagai zat pembentuk jaringan tubuh. Imbangan energi metabolisme dan protein yang digunakan dalam penelitian ini yaitu $2977,01-3041,84 \mathrm{kkal} / \mathrm{kg}$ dan protein 29,88-20,03\% juga hampir sama dengan standar kebutuhan yang direkomendasikan oleh Rasyaf (1995) bahwa imbangan energi metabolisme dan protein ransum ayam broiler sesuai fase umur yang digunakan dalam penelitian ini yaitu sebesar 2800$3300 \mathrm{kkal} / \mathrm{kg}$ dan protein adalah 18-22\%. Pesti dan Bakalli (1997) menyatakan bahwa ada hubungan linier antara protein, energi, dan persentase karkas. Protein dan energi yang terkandung dalam pakan akan digunakan untuk memproduksi daging dalam tubuh. 
Tabel 3. Rataan Persentase Karkas dan lemak abdomen

\begin{tabular}{lcccc}
\hline \multirow{2}{*}{ Variabel (\%) } & \multicolumn{4}{c}{ PERLAKUAN } \\
\cline { 2 - 5 } & $\mathrm{R}_{0}$ & $\mathrm{R}_{1}$ & $\mathrm{R}_{2}$ & $\mathrm{R}_{3}$ \\
\hline Karkas & 66,32 & 64,73 & 63,50 & 63,04 \\
Lemak Abdomen & 2,13 & 3,20 & 2,3 & 1,8 \\
\hline
\end{tabular}

Pengaruh Perlakuan Terhadap Lemak Abdominal

Lemak abdominal adalah lapisan lemak yang terdapat di sekitar gizzard dan lapisan antara otot abdominal dan usus (Salam, 2013). Persentase lemak abdominal (g) diperoleh dengan membandingkan bobot lemak abdominal dengan bobot karkas (g) dikalikan 100\%. Persentase lemak abdominal dalam penelitian ini disajikan kedalam Tabel 3.

Dari Tabel 3 dapat dilihat bahwa persentase lemak abdomen tertinggi diperoleh dari perlakuan R0 dan yang paling rendah diperoleh dari perlakuan R3. Hasil penelitian ini meskipun secara angka menunjukkan perbedaan, namun secara statistik semua perlakuan tidak menunjukkan perbedaan yang nyata. Rataan lemak abdominal ayam broiler pada penelitian ini berkisar antara 1,8-3,20\%, hasil ini tidak sama dengan pendapat Summers dan Lesson (1984) bahwa dalam keadaan normal bobot lemak abdominal berkisar antara 1,6-3,5\% dari bobot hidup. Hasil analisis menunjukkan bahwa perlakuan memberikan pengaruh berbeda tidak nyata $(\mathrm{P}>0,05)$ terhadap lemak abdominal ayam broiler, tidak adanya perbedaan yang nyata disebabkan karena kandungan energi dan protein dalam ransum hampir sama, sehingga tidak terjadi kelebihan energi yang berdampak pada tidak terjadinya penimbunan lemak. Ini sesuai dengan pendapat Maruyuni dan Wibowo (2005) bahwa pertumbuhan dan penimbunan lemak dipengaruhi oleh komposisi ransum terutama tingkat energi dalam ransum. Imbangan energi metabolisme dan protein yang digunakan dalam penelitian ini yaitu 2970,17 - 3027,6 $\mathrm{kkal} / \mathrm{kg}$ dan protein 20,88-20,03\% juga hampir sama dengan standar kebutuhan yang direkomendasikan oleh Lesson dan Summers (2008), bahwa imbangan energi metabolisme dan protein ransum ayam broiler sesuai fase umur yang digunakan yaitu sebesar $3100 \mathrm{kkal} / \mathrm{kg}$ dan protein $20 \%$. Imbangan energi dan proteinnya sama sehingga pada penelitian sampai $15 \%$ penggunaan bonggol pisang sepatu dalam ransum tidak mempengaruhi presentase lemak abdominal. Pembentukan lemak tubuh pada ayam terjadi karena adanya 
kelebihan energi yang dikonsumsi. Tetapi karena energi dalam ransum perlakuan itu sama, maka tidak ada perbedaan yang nyata sehingga tidak adanya kelebihan energi. Energi yang digunakan tubuh umumnya berasal dari karbohidrat dan cadangan lemak. Sumber karbohidrat dalam tubuh mampu memproduksi lemak tubuh yang disimpan di sekeliling jeroan dan di bawah kulit (Kubena et al., 1974).

\section{KESIMPULAN}

Berdasarkan hasil penelitian ini dapat disimpulkan bahwa penggunaan bonggol pisang sepatu (Musa paradisiaca L.) sampai dengan $15 \%$ menghasilkan presentase karkas dan lemak abdominal yang baik.

\section{DAFTAR PUSTAKA}

Achmad Gusasi dan Muh. Amir Saade, 2006. Analisis Pendapatan dan Efisiensi Usaha Ternak Ayam Potong Pada Skala Usaha Kecil. Jurnal Agrisistem V 2(1): 18584330.

Badan Standardisasi Nasional. 2009. [SNI 01-4869-1997] Potongan Karkas Broiler. Badan Standarisasi Nasional, Jakarta.

Dewi, H. R. K. 2007. Evaluasi beberapa ransum komersial terhadap presentase bobot karkas, lemak abdomen, dan organ dalam ayam broiler. Skripsi. Fakultas
Peternakan Institut Pertanian Bogor, Bogor.

Koni, 2013. Pengaruh pemanfaatan kulit pisang yang difermentasi terhadap karkas broiler. JITV. 18(2): 153157.

Kubena, L.F., J.W. Deaton, T.C. Chen dan F.N. Reece. 1974. Factors influencing the quantity of abdominal fat in broilers rearing temperature, sex age or weight, and dietary choline chloride and inositol supplementation. Poultry Sci. 53: 211-241.

Lesson, S. dan J.D. Summers. 2008. Commercial Poultry Nutrition. $3^{\text {rd }}$ ed. Nottingham (UK): Nottingham University Pr.

Maryuni, S. S. dan C. H. Wibowo. 2005. Pengaruh Kandungan Lisin dan energi metabolis dalam ransum yang mengandung ubi kayu fermentasi terhadap konsumsi ransum dan lemak ayam broiler. Journal Indonesia tropical Animal Agriculture 30: 26-33.

Pesti, G. M. dan R. L. Bakali. 1997. Estimation of the composition of broiler carcasses from their specific gravity. Journal of Poultry Sci. 76(7): 984-951.

Rasyaf, M., 1995. Beternak Ayam Petelur Jakarta: Penebar Swadaya.

Salam. S., A. Fatahilah, D. Sunarti, dan Isroli. 2013. Berat karkas dan lemak abdominal ayam broiler yang diberi tepung jintan hitam (Nigella sativa) dalam ransum selama musim panas. Sains Peternakan. 11(2):84-89.

Sumarni. 2015. Pengaruh kuantitas ransum terhadap persentase karkas, giblet dan lemak abdominal ayam 
broiler. Skripsi. Fakultas Peternakan. Universitas Halu Oleo. Kendari

Summers, J. D. dan S. Lesson. 1984. Nutrition Rempts International 40:29.

Suprayitno dan M. Indradji. 2007. Efektivitas pemberian ekstrak
Temulawak (Curcumaexanthoriza) dan Kunyit (Curcumae domestica) dan sebagai immunostimulator Flu Burung pada ayam niaga pedaging. J. Animal Production 9: 178-183.

Tamalludin, F. 2012. Ayam Broiler 22 Panen Lebih Untung. Panebar Swadaya. Depok 